\title{
Shoe Shine Entrepreneurs Social Responsibility Practices on Loyalty in Eldoret Town, Kenya
}

\author{
Matelong K. Nebert ${ }^{1}$, Sergon C. David ${ }^{1}$, Tuwei J. Gloria ${ }^{2} \&$ Cheptumo J. Irene ${ }^{2}$ \\ ${ }^{1}$ Department of Quantitative Skills and Entrepreneurial Studies, Moi University, Kenya \\ ${ }^{2}$ Department of Marketing \& Management Science, Moi University, Kenya \\ Correspondence: Matelong K. Nebert, PHD Student in the Department of Entrepreneurial Studies Moi University \\ Eldoret, Kenya. Tel: 254-72-1757-466. E-mail: nebertkip@gmail.com
}

Received: August 23, 2013

doi:10.5539/ijbm.v8n23p49
Accepted: October 10, 2013 Online Published: November 15, 2013

URL: http://dx.doi.org/10.5539/ijbm.v8n23p49

\begin{abstract}
Micro Enterprises providing services for example haircutting, key making, M-pesa, hair dressing, child care, cleaning, video selling, hawkers and shoe shining to mention but a few find it difficult to envision and understand what aspect connote high quality to consumers, and the levels of the aspects that are required to deliver high quality service. Only when these enterprises have a fairly definite knowledge on how the service they offer would be perceived by customers, then they will be able to direct these assessments in the preferred direction. However loyalty as an outcome of social responsibility practices as a key in explaining service quality is little known. This study examined the influence of the shoe shine entrepreneurer's social responsibility practices on customer loyalty in Eldoret town, Kenya. The study was based on a survey of 230 customers of shoe shine enterprises selected randomly. Questionnaires were the main instruments for collecting data. Data was analysed using descriptive and inferential statistics. Frequencies, percentages, spearman's rho correlation, phi and ordinal regression were the specific methods of analysis in this study. The findings indicated that customers consider shoe shine entrepreneurs social responsibility practices as a critical indicator of their perception of service quality. This study concludes that shoe shine entrepreneurers social responsibility practices significantly influenced customer loyalty. Equally, the findings show that shoe shine entrepreneurs need to improve on their social responsibility practices. Basing on the conclusion of this study, firstly, it is recommended that shoe shine entrepreneurs embrace social responsibility given that it could substantially enhance customer acceptance and by extension loyalty. Lastly, the study recommends the integration of social responsibility practices into relevant training for shoe shine enterprises to encourage customer loyalty.
\end{abstract}

Keywords: shoe shine entrepreneurs, service quality, social responsibility practices, customer loyalty

\section{Introduction}

The effect of entrepreneurs activities on people's quality of life leads to increase concerns about social responsibility Mahoney and Thorne (2005). The number of social responsibility researches has been debated regarding theories of academic researches Salmones, et al. (2005), practitioners Lindgreen, et al. (2009), and text books Ramasamy and Yeung (2009). Today, social responsibility is considered by individuals as an absolute necessary Swaen, and Chumptaz, (2008) and has resulted in businesses which have been expected to define their roles in society Reverte, C. (2009), Shahin, and Zairi (2007) in applying social and legal responsibilities to their businesses Lindgreen, et al. (2009). Though, many organizations presently emphasize on profitability Shen and Chang (2008), products, services, and marketing. Meanwhile, they have neglected the effect of running the business on society Shahin and Zairi (2007). Customer loyalty, a key mediating variable in explaining customer retention (Pritchard \& Howard, 1997), is concerned with the likelihood of a customer returning, making business referrals, providing strong word-of mouth, as well as providing references and publicity (Bowen \& Shoemaker, 1998). Social responsibility as an indicator of service quality determines customer loyalty (Sureshchandar, et. al., 2003). Loyal customers are less likely to switch to a competitor due to a given price inducement, and these customers make more purchases as compared with less loyal customers (Baldinger \& Rubinson, 1996). Thus the purpose of this study was to analyze customer perception of shoe shine enterprise social responsibility practices on them being loyal to these entrepreneurs. 


\subsection{Hypothesis}

Research has shown that social responsibility is one of the most significant variables in explaining service quality Sureshchandar, et al. (2003). Variables considered in this study to indicate shoe shine entrepreneurer's social responsibility practices included; reasonable pricing, equal treatment, waste disposal, employment opportunity and legal requirement ambient conditions, appealing physical facilities, neatness of shoe shine entrepreneurer's and entertainment materials. While loyalty indicators included: repeat purchase, positive word of mouth, switching intentions and referrals by the customers of shoe shine entrepreneurer's. Therefore, this research tests the influence of shoe shine entrepreneurer's social responsibility practices on customer loyalty. The specific objective of this study was to assess the influence of the shoe shine entrepreneurer's social responsibility practices on customer loyalty in Eldoret town, Kenya.

Therefore, the hypothesis for this study was formulated as follow:

$\mathrm{H}_{.01}$ There is no statistically significant relationship between shoe shine entrepreneurer's social responsibility practices and customer loyalty.

\section{Literature Review}

\subsection{Social Responsibility}

Social responsibility is an important concept, which is probably missed out completely in the quality management literature Sureshchandar, et al. (2003), they further explain that social responsibility sends strong signals toward improving an organisation image and good will in influencing customers overall evaluation of service quality provided by a particular enterprise. Further they observe that social responsibility sends signals toward improving an enterprise image and good will in influencing customers evaluation of service quality provided by entrepreneurer's. Social responsibility has repeatedly found due recognition and representation in the Malcolm Baldrige Model (US Department of Commerce and Technology Administration, 2000). A study conducted by consumer reports on customers of non-banking financials (Zemke \& Schaaf, 1990) found that the predominant customer concerns on service quality was; equal treatment, everyone, big or small, should be treated the same. They also observed that getting good service at a reasonable price. They explain further that, price is the monetary cost for a customer to buy products or services. It is the critical determinant that influences customer buying decision. Customers usually select their service entrepreneurer's strongly relying on perceived price. How much consumers are willing to pay differs due to their different needs and wants. Thus, the price perceptions to the same service may differ among individuals. Higher pricing perceived by consumers might negatively influence their purchase probabilities (Peng \& Wang, 2006). Equally, Oliver (1997) suggest that customers often judge price relating to service quality, and accordingly generate satisfaction or dissatisfaction, depending on the equity principle. If a consumer perceives price as fairness, he or she is willing to conduct this transaction with the service provider. Based on previous studies, Cheng et al. (2008) proposed that price perception can be measured by two dimensions: one is reasonableness of prices, which reflects the way that price is perceived by customers comparing to that of competitors; another is value for money, which implies the relative status of the service provider in terms of price. In general, high-quality services are considered to cost more than low-quality equivalents (Chitty et al., 2007). Many researchers have pointed out that price perception influences customer satisfaction and trust (Peng \& Wang, 2006; Cheng et al., 2008; Kim et al., 2008).

Customers often switch mainly due to some pricing issues, for example high price perceived, unfair or deceptive pricing practices (Peng \& Wang, 2006). Therefore, in order to increase customer satisfaction, it is essential for service firms to actively manage their customers' price perceptions, for example carrying out attractive pricing, offering reasonable prices mix, lower prices without decreasing quality. In enterprises, price is often used as an effective tool not only to attract new customers but at the same time maintain existing ones. Equally they suggest that an enterprise can reduce or increase its service's price as a strategic move to overcome its rivals. On the one hand, customers are willing to pay if they found price offered by an enterprise is worth of the quality of service that it delivers. In other words, right price motivates a customer to part with his or her money in exchange for something that he or she wants. On the other hand, the acceptable price for enterprises is the price that they can gain some profits. In a study investigated shopping on net customers loyalty in South Korea, Choi et al., (2006) divided their respondents into loyal and disloyal customers. They found disloyal customers had a significance influence on price sensitivity but not for loyal customers. In other words, as for loyal customers they are not affected by price, but for disloyal customers changes in price motivated them to move to other enterprises. A further study on the relationship between price and loyalty was conducted by Consuegra et al., (2007) on airline passengers in Spain, the results from the study provide empirical support, suggesting that perceived price fairness by the customers not only influences customer satisfaction but loyalty as well. Another study conducted by 
Santonen (2007), in the study the Empirical tests were conducted with survey data from customers in Finland found price to influence customer loyalty. Scarborough (2011) explains that the prices that entrepreneurers set for the service they sell are a significant factor in the image they create for their enterprises in their customers minds that will influence the image and ultimately success of their enterprises. He further allude that, as customers have become price conscious, entrepreneurers have to change their pricing strategies to emphasise quality. In addition he explains that the price relationship allows for a wide variety of highly creative pricing and marketing practices which could lead to customer loyalty. Kiruthu (2011) allude that the main reason customers leave are not price and service quality as many enterprises think. This could imply that, customers leave due to poor service or a perceived indifference of the enterprises to the customers. Equally, Letiwa (2011) allude that, the price tag is a powerful emotional trigger that gets customers to buy or not, depending on a number of easily manipulated and less understood factors. He explains that quality does not come in expensive price tags, and that there are many cheap items like bargain items that are of good quality. This could imply that high price can force customers to buy service they otherwise they would not have.

\subsection{Customer Loyalty}

Since shoe shine entrepreneurer's are very concerned about customer loyalty, they need to review and reexamine their strategies not only to sustain customer loyalty but also to remain competitive. Customer loyalty has been described to as a relationship between relative attitude towards an entity and repeat patronage behaviour (Dick \& Basu, 1994); a situation when repeat purchase behaviour is accompanied by a psychological bond (Jarvis \& Wilcox, 1977); and repeat purchase intentions and behaviours (Peter \& Olson, 1990); as a favourable attitude towards a brand in addition to purchasing it repeatedly (Day, 1969). Baumann et al., (2005) noted that Day (1969) introduced the concept that customer loyalty had both behavioral and attitudinal dimensions. The behavior approach includes criteria such as repeat purchase, share-of-wallet, and word of mouth referrals, whereas the attitudinal approach consists of criteria like commitment, trust or emotional attachment. Baldinger and Rubinson (1996) examined the link between attitude and behavior and found that the stronger the attitudinal commitment, the more likely consumers were to remain loyal, thus the use of an attitudinal measure would also indicate the behavioral dimension of customer loyalty. Woodside et al., (1989) suggests that customers are loyal as long as they continue to buy and use a good or service. This means that loyal customers repeatedly purchase a good or service over time, and hold favourable attitudes towards a good or service, or towards the company supplying the good or service. Reichheld (2003) equally states that the strongest evidence of customer loyalty is the percentage of customers who are enthusiastic enough to refer a friend or colleague to a particular good and/or service. The attitudinal approach is that customers feel a sense of belonging or commitment to the good or service. In a study of marketing intelligence, Rowley (2005) stated that there are many ways customers show their loyalty, which might include staying with a enterprise and increasing the number of frequency of purchase (McCain et al., 2005). Customer loyalty, a key mediating variable in explaining customer retention (Pritchard \& Howard, 1997), is concerned with the likelihood of a customer returning, making business referrals, providing strong word-of mouth, as well as providing references and publicity (Bowen \& Shoemaker, 1998). Loyal customers are less likely to switch to a competitor due to a given price inducement, and these customers make more purchases as compared with less loyal customers (Baldinger \& Rubinson, 1996). Customer loyalty is considered an important source of long-term business success (Rust \& Zahorik, 1993), and building a relationship with a customer is a good way to retain loyal customers in the long term (Sheaves \& Barnes, 1996). In addition, a study conducted by Barnes (1997) allude that it is unlikely that customers may be retained, often for very long periods, without a genuine quality relationship being present. Ajzen and Fishbein's (1980) theory of reasoned action suggests that if a customer receives superior service and experiences high levels of relationship quality, the positive intentions towards continuing to do business with the service organization will increase. This theory of reasoned action means as positive intentions increase, one would expect customers to act on those intentions. Thus, a customer evaluation of the quality of the relationship is central to his or her decision to continue or leave the relationship with a service provider (Hennig et. al., 2002). Smith and Wright (2004) used product quality, service quality, and firm viability in their structural equation model as direct determinants of customer loyalty in the personal computer industry, found service quality and firm viability to be statistically significant and product quality was negatively associated with customer loyalty. Hee-Su and Yoon (2004) in a research in the mobile industry researched if a mobile telephone subscriber would refer the carrier to others found that; call quality (service quality), customer mobile equipment type (product quality and features), and brand image were variables that had significant (positive) effect on customer loyalty. Other variables age, gender was not significant. Ranaweera and Neely (2003) found that perceptions of service quality had a direct linear relationship with customer retention in a study of telephone users. Level of service quality influences if a customer would refer the firm's service via word-of-mouth advertising (Anderson \& Mittal, 2000). 


\subsection{Conceptual Framework}

The conceptual framework for this study as presented in Figure 1 was based on the SERVQUAL model by Parasuraman (1985). The theoretical discussion of literature focused on the SERVQUAL which has contributed to the explanation of service quality indicators determinants and its role in enterprise performance. Empirical evidence included the service quality indicator: shoe shine entrepreneurer's social responsibility practices and customer loyalty. The SERVQUAL model was adapted in this study because it has been popular with academics and researchers to assess the customer perception of service quality. It is the assumption of this study that, customer loyalty is achieved through a process that combines service quality indicator: shoe shine entrepreneurer's social responsibility practices which included; reasonable pricing, equal treatment, waste disposal, employment opportunity and legal requirement. Shoe shine entrepreneurer's social responsibility practices were considered as independent variable in this study, while customer loyalty was considered as the dependent variable. Shoe shine entrepreneurer's integrates social responsibility in such a way they influence customer loyalty as reflected in the changes in the dependent variable measures; repeat purchase, positive word of mouth, switching intentions and referrals by the customers of shoe shine entrepreneurer's.

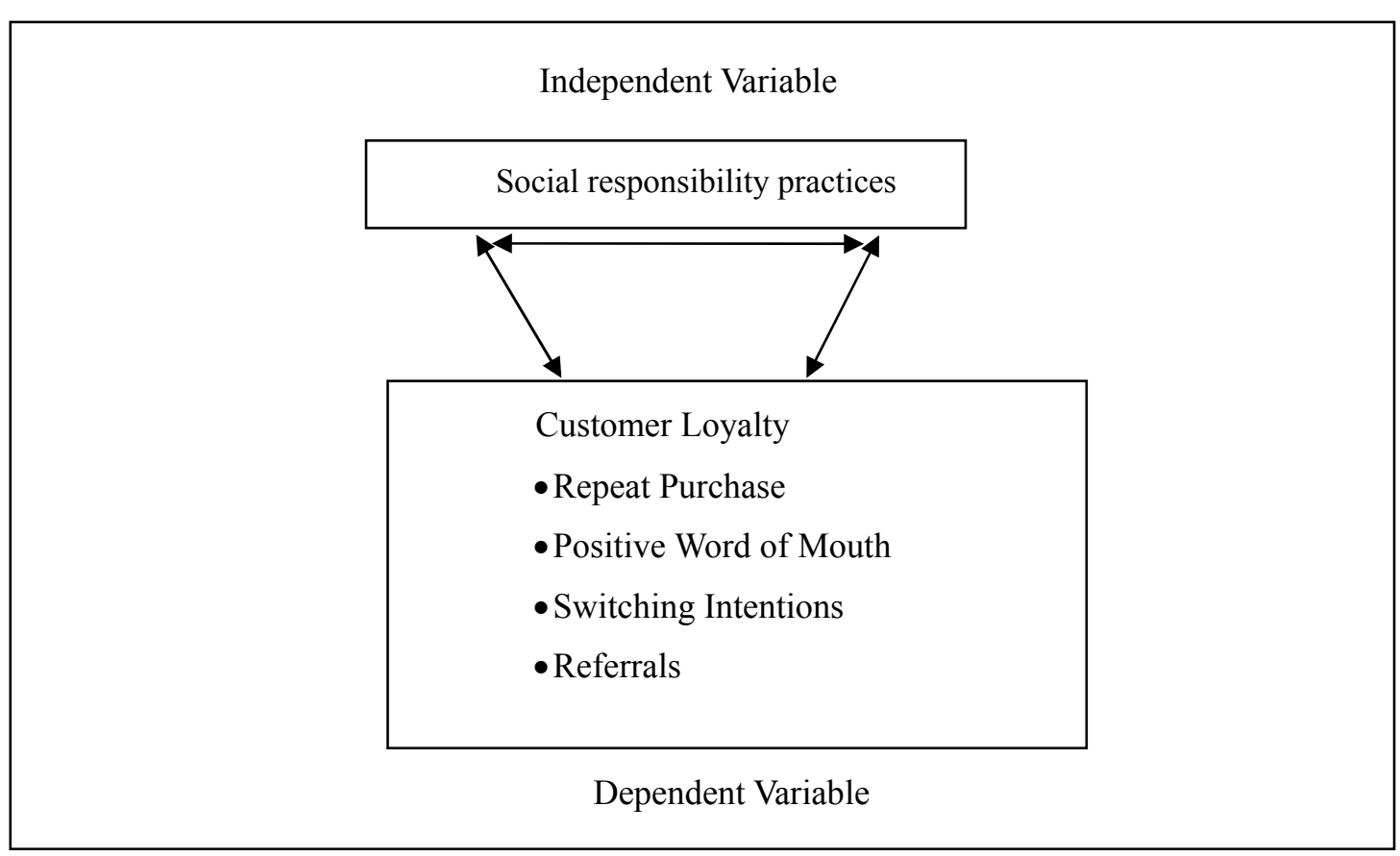

Figure 1. Conceptual framework of shoe shine entrepreneurer's social responsibility practices on customer loyalty

\section{Materials and Methods}

This chapter examined methods and procedures employed in answering the research objective of the study and data analysis. The sample for the study constituted a sampling frame drawn from Eldoret Municipal Council record year 2011. This study employed a survey strategy. The idea of a survey is that the researcher obtains the same kind of data from a large group of people or events in a standardised and systematic way and that a researcher then looks for patterns in the data that can be generalised to a large population than the group targeted (Onen \& Oso, 2009; Martyn, 2010). Survey research design falls under descriptive studies. It is associated with the deductive approach, which is a common strategy in business and management research (Saunders et. al 2009). Sample survey facilitates collection and analysis of a given set of characteristics in a population and allows collection of a large amount of data from a population in a highly economical way. This study involved asking questions, which formed the basis for deriving information (Mcburney and White, 2010; Oates, 2010; Creswell, 2012). The survey strategy allows a researcher to collect qualitative data which can be analyzed quantitatively using descriptive and inferential statistics (Saunders et al., 2009; Murray, 2010). In addition, data collected using a survey strategy can be used to suggest possible reasons for particular relationships between variables. Survey design is perceived to be authoritative by people in general and it is easily understood, and can therefore result in valuable findings if correct procedures are followed (Muijs, 2008). The study targeted 230 customers of shoe 
shine entrepreneurer's. The researcher with the aid of a research assistant administered 230 questionnaires to respondents randomly. 225 questionnaires were analysed, 5 were dropped due to respondents inability to respond to questions, this is indicated in Table 1 . The size of the sample stands at 225 with a response rate of (98\%). The high response rate was due to the personal contact approach used by the researcher as suggested by Sureshchandar et al., (2003).

Table 1. Questionnaires administered and returned for analysis

\begin{tabular}{lcc}
\hline Response & No. of questionnaires & Percentage (\%) \\
\hline Effective Questionnaires & 225 & $98 \%$ \\
Returned but Defective & 5 & $2 \%$ \\
Total & $\mathbf{2 3 0}$ & $\mathbf{1 0 0 \%}$ \\
\hline
\end{tabular}

The individual elements for this study were selected from the sampling frame using probability technique because representative samples could help in achieving the goals of the study. A pilot test was conducted to test the reliability and validity of the data collection instruments. A sample size of 30 respondents was used for statistical analysis as a rule of thumb suggested by Saunders et al., (2008). Pilot testing assisted in refining and revising data collection instruments (Oates, 2010). Data collected through pilot study was analysed and provided insights that needed to be changed. The results also provided estimation period of completing the questionnaires. Data collected had been measured at two levels nominal and ordinal scales as appropriate. The measurement levels determined analysis methods for this study (Pallant, 2001; Muijs, 2008; Saunders et. al., 2008; Howell, 2010; Sekaran \& Bougie, 2010). Data analysis aimed at searching and identifying patterns of relationships that existed among variables in this study. Data analysis involved identification of the data analysis tools, followed by data analysis using various tests by each research objective of the study. Data analysis was conducted using a computer. Statistical Package for Social Sciences (SPSS) software version 16.0 was used to analyze data and Microsoft Office Excel to format data. Whether a variable is nominal, ordinal or continuous has important consequences for type of analysis (Muijs, 2008). Data collected had been measured at two levels nominal and ordinal scales as appropriate. The measurement levels determined analysis methods for this study (Pallant, 2001; Muijs, 2008; Saunders et al., 2009; Howell, 2010; Sekaran and Bougie, 2010). Data analysis aimed at searching and identifying patterns of relationships that existed among independent and dependent variables in this study. Ethical consideration and research authorization in this study was obtained from the National Council for Science and Technology, Ref. No. NCST/RRI/1/SS-011/1558/4; subject to authority from Eldoret Municipal Council and the District Commissioner Uasin Gishu County. Prior to administering the questionnaires, a letter stating the purpose of the study and how the researcher intended to maintain privacy, confidentiality and anonymity was attached. The researcher was required to ensure high degree of tolerance, honesty and patience with customers of shoe shine entrepreneurer's while getting information from them (Creswell, 2012). Resources at the disposal of the researcher (time and finance) limited this study however, did not affect the results, given that results from the County could be generalized to other Counties where shoe shine entrepreneurer's are emerging. The possible effect of the limitations of semi-literate respondent was managed through a trained research assistant. Lastly, the scale used in this study required more specific items related to shoe shine entrepreneurer's. This could be possible with in depth interviews with customers prior to the development of the questionnaires.

\section{Results and Discussion}

\subsection{Investigating the Influence of Shoe Shine Entrepreneurs Social Responsibility Practices on Customer Loyalty}

The influence of the shoe shine entrepreneurer's social responsibility practices on customer loyalty was based on the objective of this study. This assisted in answering whether the content of shoe shine entrepreneur's social responsibility practices had a relationship with customer loyalty. Information in this section was based on shoe shine entrepreneurers social responsibility practices indicators; pricing, equal treatment, waste disposal, employment and legal requirements measured on an ordinal scale. Descriptive and inferential statistics was employed. Under descriptive statistics, analysis was by frequencies and percentages. Inferential statistics including correlation, ordinal regression, Chi-square and Phi were used. Under correlation analysis Spearman's rho correlation was used to explain whether the shoe shine entrepreneurs social responsibility practices had any relationship with customer loyalty. Ordinal regression analysis was conducted to examine the effect of shoe shine entrepreneurs social responsibility practices on customer loyalty. Chi-square test was used to test the study hypothesis that shoe shiners social responsibility practices and customer loyalty is not statistically significant. Phi was used to measure how strong the relationship was between shoe shine entrepreneurs social responsibility 
practices and customer loyalty. For the purposes of analysis for descriptive statistics, strongly agree and agree were collapsed to indicate agreement whereas strongly disagree and disagree were collapsed to indicate disagreement.

\subsubsection{Descriptive Statistics of Shoe Shine Entrepreneurs Social Responsibility Practices in Relation to Service} Quality

The frequencies of shoe shine entrepreneurs social responsibility practices in relation to service quality as perceived by the customers are presented in Table 2 . The results indicate that, 190 (84\%) of the respondents perceived that shoe shine entrepreneurs offered them good quality services at a reasonable price, the neutral response constitute of $14(6 \%)$ while $21(9 \%)$ disagreed. The results could mean that the customers were satisfied with the quality of service received and reasonable pricing charged by shoe shine entrepreneurs. The findings further indicate that, 174 (77\%) of the respondents agreed that the shoe shine entrepreneurs treated them equally with other customers to indicate service quality, only $15(7 \%)$ disagreed on this statement, while $36(16 \%)$ were neutral. This could mean that the shoe shine enterprise treated their customers equally with fairness. The results indicate that, $153(68 \%)$ of the respondents perceived negatively that the shoe shine entrepreneurs did not dispose their waste as required, $12(5 \%)$ were neutral while $60(27 \%)$ were positive. This could imply that the shoe shine entrepreneurs had no proper way of disposing their wastes making the customers feel dissatisfied. In addition, 180 $(80 \%)$ of the respondents of shoe shine entrepreneurs were positive that the shoe shine entrepreneurs was a source of employment to the members of the community, the negative response was $30(13 \%)$ while $15(7 \%)$ disagreed that the enterprises was a source of employment. This indicated that shoe shine entrepreneurs are a source of livelihood to members of the community as perceived by the customers. Lastly, 164 (73\%) of the respondents of shoe shine entrepreneurs perceived that the shoe shine entrepreneurs had not complied with the relevant legal requirements to indicate service quality for example licensed enterprises. The neutral were $3(1 \%)$ while $58(26 \%)$ agreed. This could mean that the customers perceived that shoe shine entrepreneurs had not complied with the relevant legal requirements.

Table 2. Frequencies of shoe shine entrepreneurs social responsibility practices in relation to service quality

\begin{tabular}{|c|c|c|}
\hline Indicators of Social Responsibility Practices Rank & $\mathbf{F}$ & $\%$ \\
\hline \multicolumn{3}{|c|}{ The shoe shine entrepreneurs offers me good quality service at a reasonable price } \\
\hline Agree & 190 & 84 \\
\hline Neutral & 14 & 6 \\
\hline Disagree & 21 & 9 \\
\hline Total & 225 & 100 \\
\hline \multicolumn{3}{|c|}{ The shoe shine entrepreneurs treats me equally with other customers } \\
\hline Agree & 174 & 77 \\
\hline Neutral & 36 & 16 \\
\hline Disagree & 15 & 7 \\
\hline Total & 225 & 100 \\
\hline \multicolumn{3}{|c|}{ Shoe shine entrepreneurs takes care of the environment by not disposing waste anywhere } \\
\hline Agree & 60 & 27 \\
\hline Neutral & 12 & 5 \\
\hline Disagree & 153 & 68 \\
\hline Total & 225 & 100 \\
\hline \multicolumn{3}{|c|}{ The shoe shine enterprise is a source of employment to members of the community } \\
\hline Agree & 180 & 80 \\
\hline Neutral & 30 & 13 \\
\hline Disagree & 15 & 7 \\
\hline Total & 225 & 100 \\
\hline \multicolumn{3}{|c|}{ The shoe shine entrepreneurs has complied with all relevant legal requirements } \\
\hline Agree & 58 & 26 \\
\hline Neutral & 3 & 1 \\
\hline Disagree & 164 & 73 \\
\hline Total & 225 & 100 \\
\hline
\end{tabular}




\subsubsection{Relationship between Shoe Shine Entrepreneurs Social Responsibility Practices and Customer Loyalty}

The study findings show the relationship between shoe shine entrepreneurs social responsibility practices and customer loyalty. The Spearman's rho correlation coefficient between shoe shine entrepreneurs social responsibility practices and customer loyalty is presented in Table 3 . The results show that social responsibility indicator; reasonable pricing had a significant positive $\left(\mathrm{r}_{\mathrm{s}}=0.489 \mathrm{p}=<0.05\right)$ relationship with customer loyalty. The results compare well with those of Zemke and Schaaf,(1990) whom observed that getting good service at a reasonable price, but not at the expense of quality. The study findings could imply firstly, that as price increases as a result of high quality, customer loyalty increases. Secondly, customers would wish to consume quality services at a reasonable price but not at the expense of quality. Equally, equal treatment had a significant positive relationship with customer loyalty $\left(\mathrm{r}_{\mathrm{s}}=0.337 \mathrm{p}=<0.05\right)$. The study results compare well with those of Zemke and Schaaf,(1990), in a study conducted by consumer reports on non banking financials that indicated that customers concerns on service quality was; equal treatment, stemming from the belief that everyone, big or small should be treated the same. The study findings could imply firstly that when customers perceived positively they were treated equally with others they become more loyal. Secondly, customers would wish to be treated equally with other customers by not favouring others while receiving the service. Lastly the findings could imply that the shoe shine entrepreneurs should embrace the spirit of first come first serve to achieve the trust of their customers thus achieving repeat purchases, favourable word of mouth, referrals and finally loyalty. In addition waste disposal practices had a positive significant relationship with customer loyalty $\left(r_{s}=0.390 p<0.05\right)$. Equally, employment and legal requirement had a positive significant relationship with customer loyalty $\left(r_{s}=0.370 p<0.05, r_{s}=0.514\right.$ $\mathrm{p}<0.05)$ respectively. These results compare well with those of Parasuraman (1988) and Sureshchandar et al., (2003).

Table 3. Spearman's rho correlation coefficient of shoe shine entrepreneurs social responsibility practices and customer loyalty

\begin{tabular}{lrr}
\hline Social Responsibility Indicators & Customer loyalty \\
\hline Reasonable pricing & Correlation & $0.489^{* *}$ \\
& P-value & 0.000 \\
Equal treatment & Correlation & \\
& P-value & $0.337^{* *}$ \\
Waste disposal & Correlation & 0.003 \\
& P-value & $0.390^{* *}$ \\
& & 0.001 \\
Employment opportunities & Correlation & \\
& P-value & $0.370^{* *}$ \\
& & 0.001 \\
Legal requirements & Correlation & \\
& P-value & $0.514^{* *}$ \\
& & 0.000 \\
\hline Correlation is significant at the 0.01 level (2-tailed). &
\end{tabular}

4.1.3 Ordinal Regression Analysis of Customer Loyalty with Shoe Shine Entrepreneurs Social Responsibility Practices

The ordinal regression analysis between customer loyalty with shoe shine entrepreneurs social responsibility practices is presented in Table 4 . The study findings indicate that, customers of shoe shine entrepreneurs who were negative on the quality of service offered at a reasonable price had a positive effect $(\beta=5239 \mathrm{p}<0.05)$ on customer loyalty. This could imply that if the shoe shine entrepreneurs deliver high quality services at a reasonable price the 
customers become loyal. But if the quality of service is perceived to be low by the customer the loyalty reduces. Thus the shoe shine enterprise should always strive to deliver high quality service at a reasonable price at all cost to retain and attract new customers. The results indicate that the customers who were positive that the shoe shine entrepreneurs disposed their waste appropriately had a negative effect $(\beta=-7.553 \mathrm{p}<0.05)$ on customer loyalty. This could imply that the shoe shine entrepreneurs involvement in environmental-oriented social responsibility activities is related to the improvement of positive image and reputation of their enterprises. This evidence suggests that shoe shine entrepreneurs don't have environmental concern to protect the environment in order to gain a competitive advantage resulting to a negative effect on customer loyalty. Thus the shoe shine entrepreneurs should find correct ways of disposing their waste for example they should have litter bins to dispose their waste. The results further indicate that the shoe shine entrepreneurs had not complied with the relevant legal requirements resulting to a negative effect $(\beta=-2.684 p<0.05)$ on customer loyalty. This could mean that doing legal business gives the customer confidence to consume the service without fear. The results indicate that shoe shine entrepreneurs had not complied with the legal requirements making the customer to be less loyal. This could make the customers fear associating with violent encounters with the law enforcement agents of the municipal council of Eldoret town.

Table 4. Ordinal regression of customer loyalty with shoe shine entrepreneurs social responsibility practices

\begin{tabular}{|c|c|c|c|c|c|c|}
\hline \multirow[b]{2}{*}{ Variables } & \multirow[b]{2}{*}{ Estimate } & \multirow[b]{2}{*}{ Std. Error } & \multirow[b]{2}{*}{ Wald } & \multicolumn{2}{|c|}{ 95\% Confidence Interval } & \multirow[b]{2}{*}{ Sig } \\
\hline & & & & Lower Bound & Upper Bound & \\
\hline \multicolumn{7}{|l|}{ Threshold } \\
\hline (Customer loyalty=SA) & -3.656 & 4.639 & 0.621 & -12.748 & 5.436 & 0.431 \\
\hline (Customer loyalty=A) & 3.656 & 4.639 & 0.621 & -5.436 & 12.748 & 0.431 \\
\hline$($ Customer loyalty $=\mathrm{N})$ & 8.105 & 4.760 & 2.899 & -1.225 & 17.436 & 0.089 \\
\hline \multicolumn{7}{|l|}{ Location } \\
\hline (Reasonable price $=\mathrm{D}$ ) & 5.239 & 2.489 & 4.428 & 0.360 & 10.118 & 0.035 \\
\hline (Waste disposal= SA) & -7.553 & 2.165 & 12.169 & -11.797 & -3.309 & 0.000 \\
\hline$($ Legal requirement= $\mathrm{D})$ & -2.684 & 1.102 & 5.931 & -4.844 & -0.524 & 0.015 \\
\hline Model & \multicolumn{2}{|l|}{-2 Log Likelihood } & & \multicolumn{2}{|l|}{ Chi-square } & \\
\hline Intercept only & \multicolumn{2}{|l|}{462.332} & & & & \\
\hline Final & \multicolumn{2}{|l|}{218.624} & & 243.708 & & 0.000 \\
\hline \multicolumn{7}{|l|}{ Nagelkerke $\mathrm{R}^{2}=0.749$} \\
\hline \multicolumn{7}{|l|}{ Link function: Logit } \\
\hline \multicolumn{6}{|c|}{ Key: SA- Strongly Agree, A-Agree, N- Neutral, D-Disagree } & \\
\hline
\end{tabular}

4.1.4 Hypothesis Testing: Statistical Relationship between Shoe Shine Entrepreneurs Social Responsibility Practices and Customer Loyalty

$\mathrm{H}_{.01}$ : There is no statistical significant relationship between shoe shine entrepreneurs social responsibility practices and customer loyalty.

To analyze this hypothesis, Table 4, shows that, -2log Likelihood of the model with only intercept is 462.332 while the $-2 \log$ likelihood of the model with intercept with independent variables final is 218.624 . That is the difference $462.332-218.624=243.708$ which is significant at $\mathrm{p}<0.05$ shows there is an association between shoe shine entrepreneurs social responsibility practices and customer loyalty.

$$
\begin{aligned}
\text { phi } & =\frac{243.708}{225} \\
& =1.083 \\
& =\sqrt{1.083} \\
& =1.04
\end{aligned}
$$


Table 5. Cut off points to measure the strength of the relationship

\begin{tabular}{lc}
\hline Effect Size & Strength of Relationship \\
\hline$<0.1$ & Weak \\
$<0.3$ & Modest \\
$<0.5$ & Moderate \\
$<0.8$ & Strong \\
$>0.8$ & Very Strong \\
\hline
\end{tabular}

Source: Muijs Daniel (2008).

The Phi of (1.04), refer to Table 5 shows that the relationship between shoe shine entrepreneurs social responsibility practices and customer loyalty is very strong. The $\mathrm{R}^{2}$ value of 0.749 indicates that $(75 \%)$ of the variance is statistically significant in explaining customer loyalty using the predictor. The square root of the $\mathrm{R}^{2}$ $(\sqrt{ } 0.749)=0.87$ refer to Table 4 , indicates the study model is strong fit. The chi-square value which is significant at $(p<0.05)$ level shows that shoe shine entrepreneurs social responsibility practices influence customers towards shoe shine entrepreneurs. The (95\%) confidence intervals for both dependent and independent variable does not contain a zero value. Therefore, the results indicate confidence (95\%) that there is a significant change between shoe shine entrepreneurs social responsibility practices and customer loyalty. Thus, the null hypothesis there is no statistical significant relationship between shoe shine entrepreneurs social responsibility practices and customer loyalty is rejected and the alternative hypothesis accepted and concluded there is an association between shoe shine entrepreneurs social responsibility practices and customer loyalty.

\section{Conclusions}

This study concludes that customers consider shine entrepreneurs social responsibility practices as a critical indicator of their perception of service quality. The findings show that shoe shine enterprises still need to improve on their social responsibility practices that is reasonable pricing, equal treatment, waste disposal, employment opportunity and legal requirement for them to attract and retain the existing ones hence realise repeat purchase, positive word of mouth, switching intentions and referrals by the customers.

\section{Recommendations}

The study recommends the integration of social responsibility practices through education on waste disposal, ethical aspects, personal responsibility towards society, and awareness of social and environmental issues.

The shoe shine entrepreneurs should be educated through training to practice social practices such as engaging to licensed business, equally the government should provide an enabling business environment that facilitates the integration of social responsibility in the operation of shoe shine enterprises.

\section{References}

Ajzen, I., \& Fishbein, M. (1980). Understanding Attitudes and Predicting Social Behavior. Prentice-Hall, Englewood Cliffs, N. J.

Anderson, E., \& Mittal, V. (2000). Strengthening the Satisfaction-Profit Chain. Journal of Service Research, 3, 107-120. http://dx.doi.org/10.1177/109467050032001

Baldinger, A. L., \& Rubinson, J. (1996). Brand customer loyalty: The link Between Attitude and Behavior. Journal of Advertising Research, 36(6), 22-34.

Barnes, J. G. (1997). Closeness, Strength, and Satisfaction: Examining the Nature of Relationships between Providers of Financial Services and Their Retail Customers. Psychology and Marketing, 14(8), 765-790. http://dx.doi.org/10.1002/(SICI)1520-6793(199712)14:8<765::AID-MAR3>3.0.CO;2-C

Baumann, C., Burton, S., \& Elliott, G. (2005). Determinants of Customer Loyalty and Share of Wallet in Retail Banking. Journal of Financial Services Marketing, 9(3), 231-48. http://dx.doi.org/10.1057/palgrave.fsm.4770156

Bowen, J. T., \& Shoemaker, S. (1998). Customer loyalty: A Strategic Commitment. Cornell and Hotel Restaurant $\begin{array}{lll}\text { Administration } & \text { Quarterly, } & 39(1),\end{array}$ http://dx.doi.org/10.1002/(SICI)1520-6793(199712)14:8<765::AID-MAR3>3.0.CO;2-C

Cheng, T. C. E., Lai, L. C. F., \& Yeung, A. C. L. (2008). The Driving Forces of Customer Loyalty: A Study of Internet Service Providers in the Hong Kong. International Journal of E Business Research, 4, 26-42. http://dx.doi.org/10.4018/jebr.2008100103 
Chitty, B., Ward, S., \& Chua, C. (2007). An Application of the ECSI Model as a Predictor of Satisfaction and Loyalty for Backpacker Hostels. Marketing Intelligence and Planning, 25(6), 563-580. http://dx.doi.org/10.1108/02634500710819941

Creswell, J. W. (2012). Research Design: Qualitative, Quantitative and Mixed Approaches.

Day, G. S. (1969). A Two Dimensional Concept of Brand Customer loyalty. Journal of Advertising Research, 9(3), 29-36.

Dick, S. A., \& Basu, K. (1994). Customer loyalty: Toward an Integrated Conceptual Framework. Journal of the Academy of Marketing Science, 22(2), 99-113. http://dx.doi.org/10.1177/0092070394222001

Hee-Su, K., \& Yoon, C. H. (2004). Determinants of Subscriber Churn and Customer Customer loyalty in the Korean Mobile Telephony Market. Telecommunications Policy, 28(10), 751-765.

Hennig-Thurau, T., Gwinner, K. P., \& Gremler, D. D. (2002). Understanding Relationship Marketing Outcomes: An Integration of Relational Benefits and Relationship Quality. Journal of Service Research, 4(3), 230-247. http://dx.doi.org/10.1177/1094670502004003006

Howell, D. C. (2010). Statistical Methods for Psychology (7th ed.). Belmont, CA: Cengage Wadsworth Press.

Jarvis, L. P., \& Wilcox, J. B. (1997). True Vendor Customer loyalty or Simply Repeat Purchase Behavior? Industrial Marketing Management, 6, 9-14. http://dx.doi.org/10.1016/0019-8501(77)90027-X

Kim, C. S., Zhao, W. H., \& Yang, K. H. (2008). An Empirical Study on the Integrated Framework of the e-CRM in online Shopping, Evaluating the Relationships among Perceived Value, Satisfaction and Trust Based on Customers Perspective. Journal of Electronic Commerce in Organizations, 6(3), 1-19. http://dx.doi.org/10.4018/jeco.2008070101

Kiruthu, L. (2011). Customers Don't Leave You Due to Product or Price. Tuesday Daily Nation.

Letiwa, P. (2011). The Higher the Price, the Better the Quality, Right?

Lindgreen, A., Swaen, V., \& Johnston, W. J. (2009). Corporate social responsibility: An empirical Investigation of U.S. organizations. Journal of Business Ethics, 85, 303-323. http://dx.doi.org/10.1007/s10551-008-9738-8

Mahoney, L. S., \& Thorne, L. (2005). Corporate social responsibility and long-term compensation: Evidence from Canada. Journal of Business Ethics, 53, 241-253. http://dx.doi.org/10.1007/s10551-004-5367-z

Martyn, D. (2010). The Good Research Guide for Small Scale Social Research Projects (4th ed.). McGraw-Hill.

McBurney Donald and White Theresa. (2010). Research Methods (8th ed.). USA: Wadsworth Cengage Learning.

McCain, S. C., Jang, S. C., \& Hu, C. (2005). Service Quality Gap Analysis Toward Customer Loyalty: Practical Guidelines for Casino Hotels. International Journal of Hospital Management, 24, 465-472. http://dx.doi.org/10.1016/j.ijhm.2004.09.005

Muijs, D. (2008). Doing Quantitative Research in Education with SPSS. SAGE Publications.

Murray, R. (2010). How to Write a Thesis (2nd ed.). England: Open University Press, McGraw-Hill Education.

Nassiuma, D. (2000). Survey Sampling: Theory and Methods. Nairobi University Press.

Oates, B. J. (2010). Researching Information Systems and Computing. Sage Publication.

Oliver, R. L. (1997). Satisfaction. A Behavioural Perspective on the Consumer, New York: McGraw Hill

Onen, D., \& Oso, W. Y. (2009). A General Guide to Writing Research Proposal and Report (Revised edition). Shima Printers and Stationers Ltd.

Pallant, J. (2001). SPSS Survival Manual. Buckingham: Open University Press.

Parasuraman, A., Zeithaml, V. A., \& Berry, L. L. (1985). A Conceptual Model of Service Quality and Its Implications for Future Research. Journal of Marketing, 49, 41-50. http://dx.doi.org/10.2307/1251430

Parasuraman, A., Zeithaml, V. A., \& Berry, L. L. (1988). SERVQUAL: A Multiple Item Scale For Measuring Consumer Perceptions of Service Quality. Journal of Retailing, 64, 12-40.

Peng, L. Y., \& Qing, W. (2006). Impact Relationship Marketing Tactics on Switcher and Stayers in a Competitive Service Industry. Journal of Marketing Management, 22, 25-59. http://dx.doi.org/10.1362/026725706776022263

Peter, J. P., \& Olson, J. C. (1990). Consumer Behavior and Marketing Strategy. Richard D. Irwin, Inc., 
Homewood, IL.

Pritchard, M. P., \& Howard, D. R. (1997). The Loyal Traveler: Examining a Typology of Service Patronage. Journal of Travel Research, (Spring), 2-10.

Ramasamy, B., \& Yeung, M. (2009). Chinese consumers' perception of corporate social responsibility (CSR). Journal of Business Ethics, 88, 119-132. http://dx.doi.org/10.1007/s10551-008-9825-x

Ranaweera, C., \& Neely, A. (2003). Best Student Paper some Moderating Effects on the Service Quality-Customer Retention Link. International Journal of Operations \& Production Management, 23, 230-248. http://dx.doi.org/10.1108/01443570310458474

Reichheld, F. F. (2003). The One Number You Need to Grow. Harvard Business Review, 485-491.

Reverte, C. (2009). Determinants of corporate social responsibility disclosure ratings by Spanish Listed Firms. Journal of Business Ethics, 88, 351-366. http://dx.doi.org/10.1007/s10551-008-9968-9

Rowley, J. (2005). The C's of Customer Loyalty. Marketing Intelligence and Planning, 23(6). 574-581. http://dx.doi.org/10.1108/02634500510624138

Rust, R. T., \& Zahorik, A. J. (1993). Customer Satisfaction, Customer Retention and Market Share. Journal of Retailing, 69(2), 193-215. http://dx.doi.org/10.1016/0022-4359(93)90003-2

Salmones, M. D. M. G., Crespo, A. H., \& Bosque, J. R. (2005). Influence of Corporate Social Responsibility on Loyalty and Valuation of Service. Journal of Business Ethics, 61, 369-385. http://dx.doi.org/10.1007/s10551-005-5841-2

Saunders, M., Lewis, P., \& Thornhill, A. (2009). Research Methods for Business Students (5th ed.). Prentice Hall.

Scarborough, N. M. (2011). Essentials of Entrepreneurship and Small Business Management (6th ed.).

Sekaran, U., \& Bougie, R. (2010). Research Methods for Small Business (5th ed).

Shahin, A., \& Zairi, M. (2007). Corporate governance as a critical element for driving excellence in corporate social responsibility. Journal of Quality \& Reliability Management, 24, 753-770. http://dx.doi.org/10.1108/02656710710774719

Sheaves, D. E., \& Barnes, J. G. (1996). The Fundamentals of Relationships: An Exploration of the Concept to Guide Marketing Implementation. In Swartz, T. A., David, E. B., \& Stephen, B. (Eds.), Advances in Services Marketing and Management (pp. 215-245). JAI Press Inc., Connecticut, USA.

Shen, C. H., \& Chang, Y. (2008). Ambition versus conscience, does corporate social responsibility pay off? The Application of Matching Methods. Journal of Business Ethics, 88, 133-153. http://dx.doi.org/10.1007/s10551-008-9826-9

Smith, R. E., \& Wright, W. F. (2004). Determinants of Customer loyalty and Financial Performance. Journal of Management Accounting Research, 16, 183-205. http://dx.doi.org/10.2308/jmar.2004.16.1.183

Sureshchandar, G. S., Rajendran, C., \& Anantharaman, R. N. (2003). Customer Perception of Service Quality in the Banking Sector of a Developing Economy: A Critical Analysis. International Journal of Bank Marketing 21(5), 233-242. http://dx.doi.org/10.1108/02652320310488411

Swaen, V., \& Chumptaz, R. C. (2008). Impact of Corporate social responsibility on consumer trust. Journal of Application on Marketing, 23, 7-33.

US Department of Commerce and Technology Administration. (1997). Malcolm Baldrige National Quality Award Guidelines. Washington, DC: NIZT.

Zemke, R., \& Schaaf, D. (1990). The Service Edge. New York, NY: Penguin Books.

\section{Copyrights}

Copyright for this article is retained by the author(s), with first publication rights granted to the journal.

This is an open-access article distributed under the terms and conditions of the Creative Commons Attribution license (http://creativecommons.org/licenses/by/3.0/). 